\title{
Energy supply in Malawi: Options and issues
}

\author{
John L Taulo \\ Department of Mechanical \& Mechatronic Engineering, Stellenbosch University, South Africa
}

Kenneth Joseph Gondwe

Department of Mechanical Engineering, University of Malawi, Blantyre, Malawi

\section{Adoniya Ben Sebitosi}

Department of Mechanical \& Mechatronic Engineering, Stellenbosch University, South Africa

\section{Abstract}

Inadequate energy supply is one of the major problems confronting Malawi and limiting its social, economic and industrial development. This paper reviews the current status of energy supply and demand in Malawi; examines the major sources of

and $5.27 \mathrm{kWh} / \mathrm{US} \$$ for the REF, AGS and MGS, respectively in the year 2030. In conclusion, the paper outlines strategies that could be utilized to ensure adequate supply of modern energy which is a key ingredient for achieving sustainable social and economic growth.
\end{abstract} energy, current exploitation status and their potential contribution to the electricity supply of the country; discusses key issues facing the energy sector; and identifies broad strategies to be implemented to tackle the energy supply challenges. Using secondary data for its critical analysis, the paper also presents modelling of long-term energy demand forecast in the economic sectors of Malawi using the Model for Analysis of Energy Demand (MAED) for a study period from 2008-2030. Three scenarios namely reference (REF), moderate growth (MGS) and accelerated growth (AGS) were formulated to simulate possible future long-term energy demand based on socio-economic and technological development with the base year of 2008. Results from all scenarios suggest an increased energy demand in consuming sectors with biomass being a dominant energy form in household and industry sectors in the study period. Forecast results reveal that energy demand will increase at an annual growth rate of $1.2 \%$ and reach 5160 ktoe in 2030 under REF scenario. The growth rates for MGS and AGS are projected at $1.5 \%$ each reaching 4639 ktoe and 5974 ktoe in 2030, respectively. The final electricity demand of about 105 ktoe in the base year will grow annually at average rates of $13.8 \%, 15.3 \%$ and $12.6 \%$ for REF, AGS and MGS, respectively. Over the study period 2008-2030 the annual electricity per capita will increase from about $111 \mathrm{kWh}$ to 1062, 1418 and $844 \mathrm{kWh}$ for the REF, AGS and MGS, respectively. The final energy intensity will decrease continuously from about $13.71 \mathrm{kWh} / \mathrm{US} \$$ in the base year to $3.88 \mathrm{kWh} / \mathrm{US} \$, 2.98 \mathrm{kWh} / \mathrm{US} \$$
Keywords: energy, energy supply, energy demand, scenario analysis, MAED, Malawi

\section{Introduction}

Energy supply has become a growing concern in Malawi and an important factor towards achieving growth and development. Future economic growth crucially depends on the long term availability of energy from sources that are affordable, accessible, and environmentally friendly. However, the country is faced with serious energy supply problems including, rising energy and electricity demand; insufficient power generation capacity; increasing high oil import bills; lack of investment in new power generation units; high transmission and distribution costs, transmission losses; poor power quality and reliability; heavily subsidized pricing; insufficient focus on alternative energy sources; and lack of access to modern electricity for a large segment of the population (MCC,2011).

In addition, the country faces a widening gap between electricity demand and supply which is being exacerbated by urbanisation, economic development, population growth and rural electrification (MCA, 2010). Electricity demand has been growing consistently at $6-8 \%$ per annum (GoM, $2010 a)$. As a result, the existing system is greatly strained and the frequency of blackouts or brownouts is increasing, constraining industrial pro- 
duction and provision of socioeconomic services as well as deterring foreign investment.

Furthermore, inefficient production and unsustainable use of biomass energy in Malawi is contributing to environmental degradation, such as high deforestation, desertification, and soil erosion. The use of wood, charcoal and crop residues as fuel also results in indoor air pollution which causes severe human health impacts directly to the users, especially rural women. Moreover, the task of gathering traditional supplies of fuelwood is time consuming and exhausting. This burden is borne by women and children, who are then diverted from other activities such as education and farming that could eventually have improved their productivity and living conditions. Thus, improving the energy supply situation and, in particular increasing access to electricity, are of prime concern in Malawi.

Very few studies on the country's energy sector and strategies for the future are presented in the literature. Kaunda (2013) investigated the energy situation and small scale hydropower potential and application status in Malawi. Kaunda and Mtalo (2013) presented work that studied the impacts of environmental degradation and climate change on power generation in Malawi. Although Gamula et al. (2013) provided an overview of the energy sector development in Malawi and the likely scenario in 2050, their study did not take into account fuel prices, technology costs as well as renewable energy potentials. Jumbe (2004) examined the relationship between electricity consumption and GDP for Malawi for the period 1970-1999. The study found bidirectional causality between electricity consumption and GDP. Openshaw (2010) studied biomass energy, employment generation, and its contribution to poverty alleviation. Despite these studies, there has been comparatively limited interest in examining the energy supply situation, options and issues associated with it in Malawi. Consequently, there has been a corresponding dearth of research. The present article aims at filling this gap in the literature.

This paper highlights the energy supply deficit the country faces and its impacts on social economic development against the background of rich endowment of renewable energy resources. It also critiques the constraints that are hindering growth in electric power generation, presents plausible alternative pathways and discusses on key issues that stakeholders must take on board to bring improvement in the energy supply.

\section{Current status of energy demand and supply in Malawi}

Malawi is located in South-east Africa and has a total area of $118484 \mathrm{~km}^{2}$ and a population of about 15.6 million inhabitants, with an annual growth rate of $2.8 \%$ (NSO, 2009). The GDP of the country in the year 2010 was US $\$ 5.7$ billion with the following composition by sector: services $52 \%$, $33 \%$ agriculture, and $15 \%$ industry. Agriculture contributes $60 \%$ of total export earnings and employs $84 \%$ of total labour force. The major export crops are tobacco, tea, sugarcane and cotton; tobacco alone accounts for about $67 \%$ of the export earnings from agriculture (World Bank, 2011). While the country's GDP has grown steadily by an average of $7 \%$ per annum over the last five years, electricity generation and supply has remained stagnant. With rapid increase in population and industry, energy needs are on the rise. Electricity shortages are estimated to cost the country around 2-3\% of GDP (MCA, 2010).

Primary energy supplies of the country consist of hydropower, biomass, petroleum products, coal and other renewable energy sources. ${ }^{1}$ Petroleum and petroleum products are imported and the country spends about $10 \%$ of its foreign currency reserves on the import of petroleum products (GoM, 2003). On the other hand, the country's vast resource of renewable hydropower energy remains virtually unexploited. More than $84.7 \%$ of the total population in Malawi live in rural areas and has access only to wood and paraffin as major energy resources. Currently, the overall electrification rate in Malawi is $10 \%$, with $37 \%$ of the urban population and only $2 \%$ of the rural population having access to electricity (NSO, 2009). Per capita consumption-often viewed as a key index of development- in the country, is only $290 \mathrm{~kg}$ of oil equivalent (kgoe) per person of primary energy compared to the averages of 563 kgoe for low income countries and the world average of $1820 \mathrm{kgoe}$ (IEA, 2010). Similarly, the per capita consumption of electrical energy is still low, estimated at $93 \mathrm{kWh}$ per year compared with $432 \mathrm{kWh}$ and $2167 \mathrm{kWh}$ per year for Sub-Saharan Africa and world averages, respectively (World Bank, 2001).

There is a strong correlation between human development index (HDI) and per capita electricity consumption. According to UNDP Human Development Report of 2013, Malawi's per capita consumption and its corresponding HDI of 0.418 is well below the sub-Saharan regional and global averages. Malawi needs to reach the first critical threshold of $500 \mathrm{kWh}$ per year use.

Table 1 presents the distribution of primary energy supply for the years 1996 and 2008. Biomass remains the main primary energy source and accounted for $88.5 \%$ of the total energy supply for country. Petroleum fuels, electricity and coal supplied $6.4 \%, 2.4 \%$, and $2.8 \%$, respectively. Total primary energy supply in 1996 was 2741.32 kilo tonnes of oil equivalent (ktoe) and increased to 4125.97 ktoe in 2008 (GoM, 2010b). The major sources of traditional biomass are firewood, charcoal, and agricultural residues, and their shares in 
energy supply are approximately $87 \%, 6.4 \%$ and $6.6 \%$, respectively (Openshaw,2010). The share of commercial fuels including petroleum products, hydro and coal is $11.6 \%$. The contribution of petroleum products in energy supply in Malawi has increased from $4.11 \%$ in 1999 to $6.4 \%$ in 2010 .

Similarly, the contribution of coal in Malawi's primary energy supply in the country has increased from $1 \%$ in 1996 to $2.8 \%$ in 2010 , primarily due to rapid expanding use of coal in industries. The contribution of renewable energy sources is only $0.3 \%$, which is very low in comparison to other countries (GoM, 2010c). However, there is need to increase both coal and electricity consumption as a means of increasing the energy mix for the country. There has also been an increase in the percentage of households with access to electricity from $4 \%$ in 2005 to $10 \%$ in 2010 . This is partly due to successful implementation of rural electrification program, which has increased the number of trading centres connected to electricity from 45 in 2005 to 182 in 2010. Furthermore, there has been a decline in the proportion of population using solid fuels from $94.8 \%$ in 2005 to $88.4 \%$ in 2010 (GoM, 2012).

Table 1: Primary energy supply share in Malawi

\begin{tabular}{lcccc}
\hline $\begin{array}{l}\text { Primary } \\
\text { energy supply }\end{array}$ & \multicolumn{2}{c}{$\begin{array}{c}\text { Amount } \\
\text { (ktoe) }\end{array}$} & \multicolumn{2}{c}{$\begin{array}{c}\text { Share } \\
\text { (\%) }\end{array}$} \\
\hline Biomass & 1996 & 2008 & 1996 & 2008 \\
\hline Coal & 2577.3 & 3640 & 89 & 88 \\
\hline Petroleum & 50.16 & 98.68 & 2 & 2 \\
\hline Hydro & 200.1 & 280.07 & 7 & 7 \\
\hline Solar & 64.5 & 104.82 & 2 & 3 \\
\hline Total & 0 & 2.4 & 0 & 0 \\
\hline
\end{tabular}

Figures 1(a) and (b) show the final energy consumption per sector and fuel for the years 1996 and 2008. The household sector is the largest single consumer of final energy, with 3455 ktoe, followed by transport, industrial, agricultural and natural

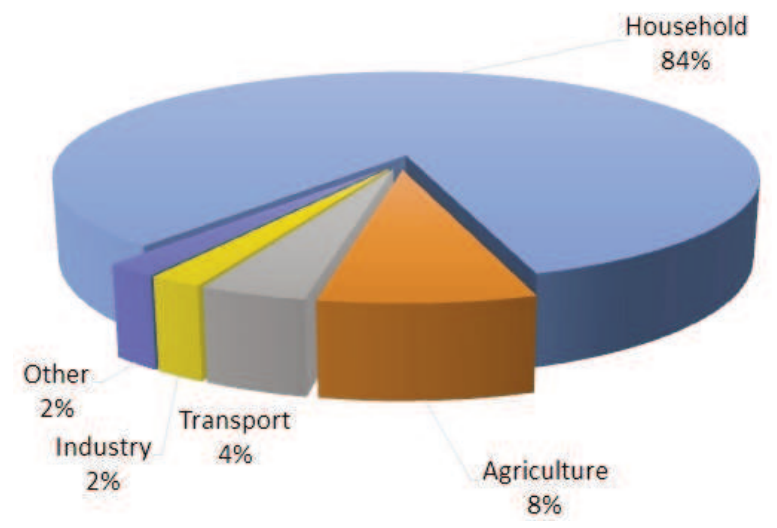

Figure 1(a): Total energy use, percent by sector, 1996 resources, and service with 201 ktoe, 180 ktoe, 168 ktoe and 106 ktoe, respectively. Rural households utilized the greatest proportion of the energy $(77 \%)$ out of which $97 \%$ is of biomass origin and comprises mainly of firewood, charcoal and crop residues. The principal end uses of fuel are cooking and lighting. Firewood, charcoal and crop residues are used for cooking while paraffin is used for lighting. The main energy uses in the industrial sector are process heating, motive power, and lighting. Coal supplied $53.3 \%$ of total industrial energy demand, and electricity and biomass sources supplied $17.8 \%$ and $27.7 \%$ of the total energy demand, respectively (GoM, 2010c).

The energy consumption of the transport sector will be an important factor for the future of energy demand supply projection and has the potential to become the highest sector of energy consumption. The transport sector, in spite of consuming very little energy (5\%) needs significant amounts of the country's foreign currency earnings to purchase this energy from abroad. The expenditure on petroleum fuels is growing through time because of price increases on the world petroleum market and the increment in vehicle imports. This is greatly influencing the trade balance of the country. Also the revenue to finance social services like health, education, and other infrastructure is significantly reduced by the pressure caused by the national transport energy expenditure.

\section{Power energy status}

\subsection{Power generation capacity}

Grid electricity is the main source of modern energy in Malawi. The major sources of electricity are hydropower and thermal. Table 2 shows the installed capacity of various generating plants and grid stations in Malawi. Total installed capacity for electricity generation as at March 2015 is 430 MW, in which $80 \%$ is contributed by the Electricity Supply Corporation of Malawi (ESCOM, 2011). The rest of the energy is supplied by the private sector at $19.6 \%$. Total installed capacity of the grid

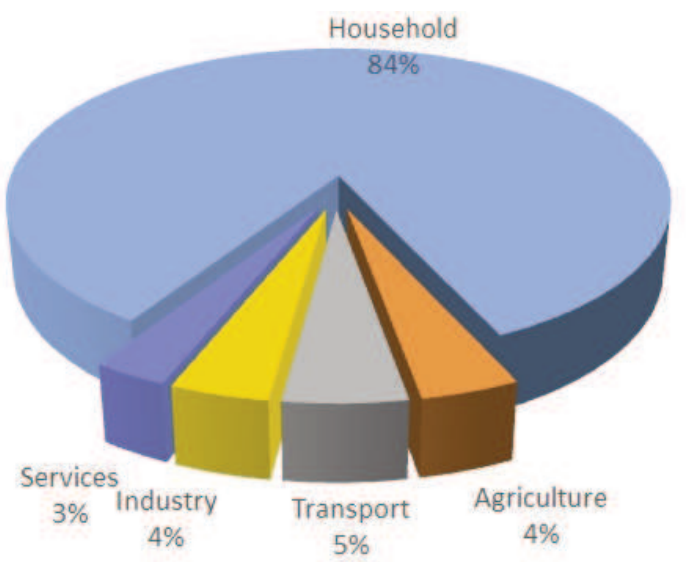

Figure 1(b): Total energy use, percent by sector, 2008 
Table 2: Installed capacities (MW) of generating plants from different sources

\begin{tabular}{|c|c|c|c|c|c|c|}
\hline Power plant & Bagasse & Diesel & Hydro units & Solar/wind hybrid & Solar PV & Total \\
\hline Nkula A & & & $3 \times 8$ & & & 24 \\
\hline Nkula B & & & $5 \times 20$ & & & 100 \\
\hline Tedzani I & & & $2 \times 10$ & & & 20 \\
\hline Tedzani II & & & $2 \times 10$ & & & 20 \\
\hline Tedzani III & & & $2 \times 26.35$ & & & 52.7 \\
\hline Kapichira I & & & $2 \times 32.4$ & & & 64.8 \\
\hline KapichiraII & & & $2 \times 32.4$ & & & 64.8 \\
\hline Wovwe & & & $3 \times 1.5$ & & & 4.5 \\
\hline$\overline{\text { Mzuzu }}$ & & $1 \times 1.1$ & & & & 1.1 \\
\hline Chizumulu & & $1 \times 0.3$ & & & & 0.3 \\
\hline Likoma & & $3 \times 0.25$ & & & & 0.75 \\
\hline Dwangwa & $2 \times 3.5$ & & & & & 7 \\
\hline Nchalo & $1 \times 11.5$ & & & & & 11.5 \\
\hline Kayerekera & & $1 \times 10$ & & & & 10 \\
\hline Others & & 51.5 & & $3 \times 0.025$ & & 51.58 \\
\hline Lujeri & & & 0.84 & & & 0.84 \\
\hline Lilongwe & & & & & 0.87 & 0.87 \\
\hline Total & 18.5 & 63.65 & 347.14 & 0.075 & 0.87 & 430.2 \\
\hline
\end{tabular}

connected hydropower system and isolated small hydropower is around 351.8 MW and 4.5 MW, respectively (Gooneratne and Visser, 2010). The installed capacity and electricity generation of hydropower plants accounts for $80.2 \%$ and $98 \%$, respectively, of the country's total power generation. In addition to this, there are a number of cogeneration and diesel power plants with a total installed capacity of 70 MW (GoM, 2010a), which are not connected to the grid and owned by the private sector. Currently, $0.3 \%$ power is produced from different renewable energy sources such as solar and solar/wind hybrid. The installed capacity of solar and solar/wind hybrid based power station is estimated to be $1 \mathrm{MW}$.

\subsection{Electricity demand}

Figure 2 shows electricity generation and demand between 1999 and 2011. Grid electricity has increased from 1031.8 to 1887.7 GWh between 1999 and 2011, representing an average annual increase of 6\%. Between 1996 and 2011, the average maximum demand for electricity had increased from 190.2 MW to 277 MW. Currently the system average peak load is around $300 \mathrm{MW}$, while the available capacity is around $255 \mathrm{MW}$ representing a deficit of $14 \%$. Under the business as usual (BAU) scenario, the projected electricity demand will be $598 \mathrm{MW}$ in 2015, $874 \mathrm{MW}$ in 2020, $1193 \mathrm{MW}$ in 2025, and $1597 \mathrm{MW}$ in 2030 (GoM, 2010a). Further, an estimated step load increase of $37 \mathrm{MW}$ per year is expected for up to 2020 . The load fore-

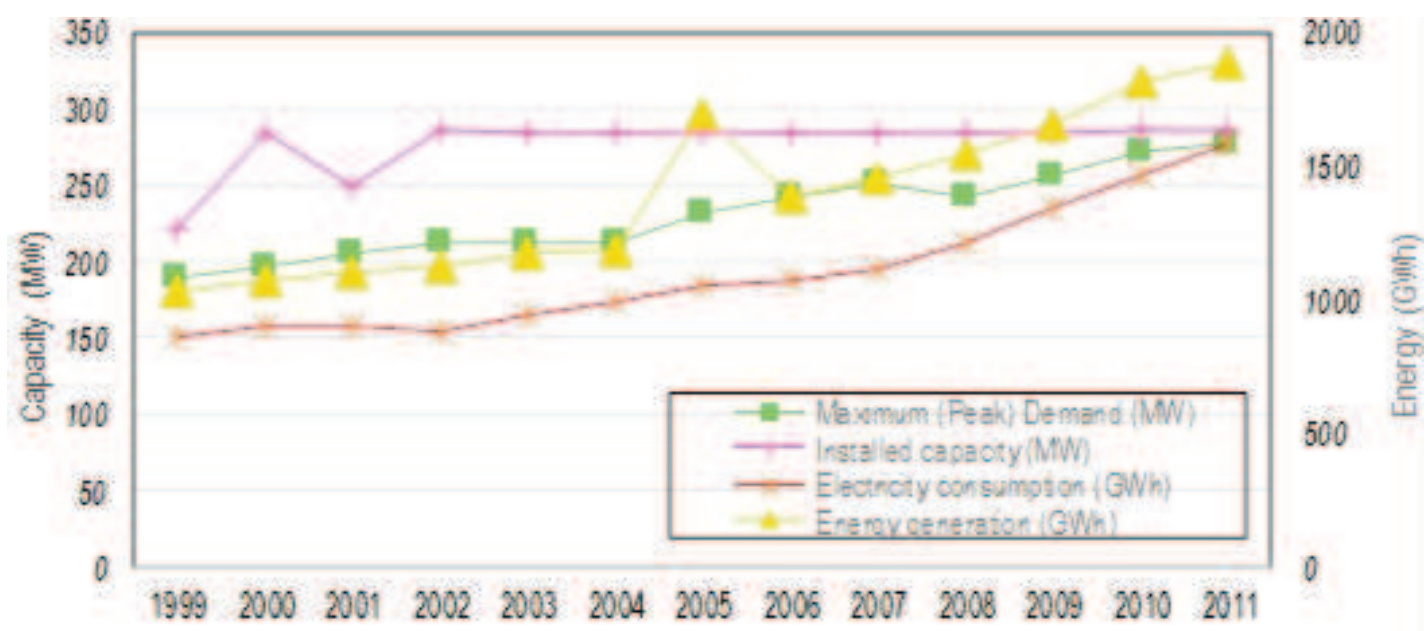

Figure 2: The total installed electricity-generation capacity and the peak demand in Malawi 
casts also expects an average demand increase of 5 MW per year in the residential sector alone due to increased electrification. The supply and demand in the Malawi's power sector show a trend of significant shortage in the foreseeable future, due to an increase in demand averaging $7 \%$ per year (GoM, 2010c). The annual electricity consumer connections have continued to rise sharply over the last five years, increasing from 175, 167 in 2008/9 to 204, 955 in 2011/12 financial years (ESCOM, 2011). The total number of customers connected to electricity was 218,164 as of June 2012 representing $10 \%$ access, which still compares poorly to the average of $32 \%$ for developing countries (Kiplagat, Wang and Li, 2011).

\subsection{Generation capacity expansion}

Future generation plants consist of conventional hydro power schemes and coal fired stations as well as a nuclear power plant. Total planned generation capacity will grow from $430 \mathrm{MW}$ in the base year to over 2764 MW (GoM, 2010a). Hydro will maintain its position as the main driver of the electricity sector in the short to medium term. Hydropower capacity is expected to increase from $351 \mathrm{MW}$ in the base year to about 1985 MW by 2050. Coal and nuclear capacity are expected to increase from nil to $420 \mathrm{MW}$ and $125 \mathrm{MW}$ by 2050, respectively. Renewable energy technologies such as small hydro, geothermal and dendro thermal are not captured by the least economic cost based planning process being followed by government. However, it is estimated that a technical potential of about 150 MW of small hydropower (GoM, 1997), over 100 MW of dendropower (Venedaal, 1996) and over 200 MW (Gondwe et al., 2012) of geothermal power exists in the country. The expansion of grid connected small-hydro schemes and the introduction of dendro thermal systems and geothermal power systems would reduce the need for fossil fuel based power generation, resulting in reduced greenhouse gas emissions.

\section{Energy outlook for Malawi \\ 4.1 Scenario development}

To analyse the future development of the Malawian energy and electrical demand, the computer program MAED (Model for Analysis of Energy Demand has been applied. MAED is a bottom-up approach model widely used for forecasting medium to long-term energy demands. It evaluates the future energy needs based on medium and longterm scenarios of socioeconomic, technological and demographic development in a country or region. Key consumption sectors that are considered in MAED comprises of industry, transport, household and service. The industry is further divided into sub-sectors that comprise of agriculture, construction, mining (ACM) and, manufacturing while trans- port sector is sub-divided into passenger and freight transport. Population is a major driver of energy demand, while its most important determinant is the level of economic activity and its structure measured by the total gross domestic product (GDP) alongside the various sectors of the economy. Population of Malawi is expected to grow from 13.077 million in 2008 to 19.696 million by 2030 at an average annual rate of $2.8 \%$. The GDP growth rate is projected at $7 \%$ per year in the long term. The results of the study carried out using the MAED model are discussed in this section.

\subsection{Simulation results and analyses}

\subsubsection{Total final energy demand projection}

Figure 3 presents the projected total final energy demand from 2008 to 2030 for the three scenarios in this study: REF, AGS and MGS. The average annual growth rate will amount to $1.2 \%, 1.5 \%$ and $1.5 \%$ for REF, AGS and MGS, respectively. Total final energy demand will increase from 4125 ktoe in the base year to 5160, 5974 and 4639 ktoe in the year 2030 for REF, AGS and MGS, respectively. Results further show that energy balance for all scenarios will be dominated by biomass followed by electricity and imported energy (fossil and motor fuels). Biomass dominates both scenarios by having an average share of $39.5 \%, 34.7 \%$ and $43 \%$ of the total final energy demand for REF, MGS and AGS, respectively. Moreover, results indicate that imported energy have an average of $25.1 \%$ in 2030 for all scenarios. Electricity will command a share of $34.8 \%, 40.2 \%$ and $43 \%$ of final energy demand in REF, MGS and AGS scenarios, respectively in 2030.

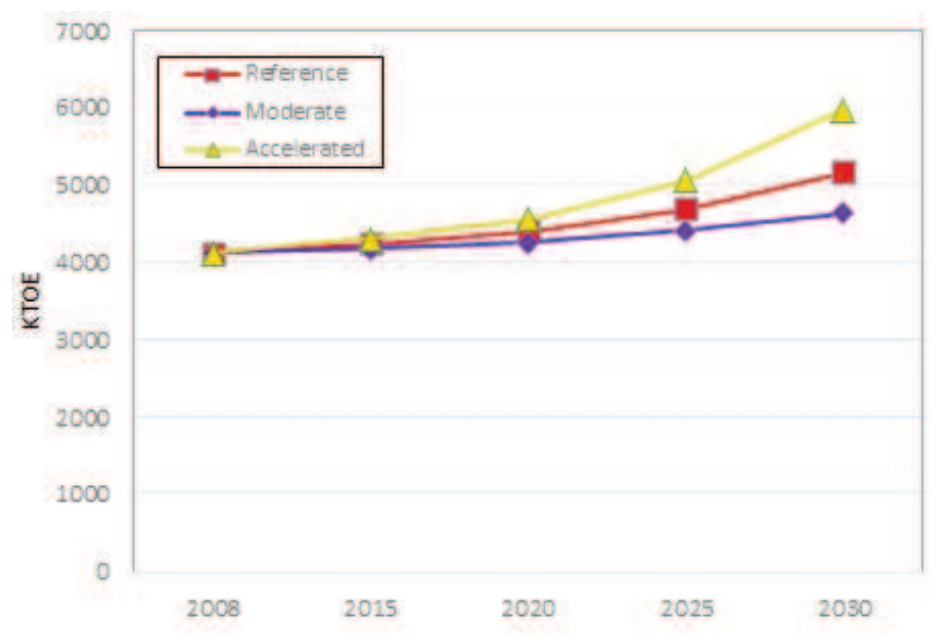

Figure 3: Total final energy demand projection in Malawi

\subsubsection{Final energy demand by energy form}

Table 3 shows the development of final energy demand distributed by the energy form of consumption. Compared to the REF and AGS scenarios, MGS show less projected energy demand growth rate as the final energy is less by 526 ktoe than REF whereas AGS is higher by 809 ktoe both 
in 2030. The growth rate of biomass demand is estimated to amount at $-3.03 \%,-2.96 \%$ and $-3.13 \%$ for REF, AGS and MGS scenario respectively. Electricity demand annual growth rate is projected to increase at the rate of $13.78 \%, 15.29 \%$ and $12.6 \%$ for the REF, AGS and MGS scenario, respectively. Fossil fuel for thermal applications projected demand is expected to increase at $5.39 \%, 6.73 \%$ and $4.45 \%$ for the REF, AGS and MGS scenario, respectively. Motor fuels demand of about 264 ktoe will grow annually at average rates of $5.95 \%$, $6.23 \%$ and $5.7 \%$; reaching $941,997.3$ and 894.2 ktoe in 2030 for the REF, AGS and MGS scenario, respectively. Solar energy demand annual growth rate is projected to increase at a rate of $12.45 \%$, $12.61 \%$ and $12.28 \%$ for the REF, AGS and MGS scenario, respectively.

\subsubsection{Final energy demand by sector}

Table 4 shows the REF, AGS and MGS scenario results for energy demand in different sectors for the period 2008-2030. The household sector is expected to dominate total final energy consumption demand over the outlook period, accounting for $55 \%$ share by 2030 . Industry, transport and service demands are estimated to account for $25 \%, 16 \%$ and $5 \%$, respectively, of the country's final energy demand by 2030. The household sector will have total final energy demand of 2859.22 ktoe in 2030 for REF scenario whereas AGS and MGS will have 3063.67 and 2859.22 ktoe, respectively. Transport sector depicts higher final energy demand in passenger transport as compared to freight transport in all scenarios. Final energy demand in transport sector in REF scenario for 2030 will be 497.93 ktoe for passenger transport as compared to $253.07 \mathrm{ktoe}$ for freight transport. The analysis shows that manufacturing is the leading sub-sector in consumption of final energy demand as compared to agriculture, construction and mining (ACM) combined together, for all scenarios.

\subsubsection{Electricity demand forecast}

Figures 4 and 5 depict the comparison in electricity demand growth and peak projects for the REF, AGS and MGS scenarios. The share of electricity consumption will increase from $2.54 \%$ in the base year to about $34.81 \%, 40.25 \%$ and $30.8 \%$ for the REF, AGS and MGS, respectively. The final electricity demand of about 105 ktoe in the base year will grow annually at average rates of $13.8 \%, 15.3 \%$ and $12.6 \%$ for REF, AGS and MGS, respectively. According to these rates, the final electricity demand will reach 1798 ktoe for the REF, 2402 ktoe for the AGS and 1429 ktoe starting from the base year value.

The system peak demand in Malawi is forecasted to increase from the suppressed demand of 233 MW in the base year to 4274 MW in 2030 under REF scenario, which translates to an annual growth rate of $14 \%$. The growth rates for AGS and MGS are projected at $15 \%$ and $13 \%$ reaching $5352 \mathrm{MW}$ and $3622 \mathrm{MW}$, respectively. The system load factor decreases from $67.5 \%$ in the base year to $60.94 \%$, $64.65 \%$ and $57.47 \%$ in REF, AGS and MGS, respectively. In order to meet the future demand,

Table 3: Energy demand by energy form

\begin{tabular}{lccccccc}
\hline Energy source & \multicolumn{3}{c}{ Growth rate (\%) } & \multicolumn{2}{c}{ 2008 (ktoe) } & \multicolumn{2}{c}{ 2030 (ktoe) } \\
& BAU & AGS & MGS & Base year & BAU & AGS & MGS \\
\hline Traditional biomass & -3.03 & -2.96 & -3.13 & 3640 & 1849 & 1880 & 1806.6 \\
\hline Modern biomass & 26.96 & 26.96 & 26.96 & 0 & 191 & 191 & 191 \\
\hline Electricity & 13.78 & 15.29 & 12.6 & 105 & 1798 & 2402 & 1428.7 \\
\hline Solar thermal & 7.06 & 8.96 & 5.14 & 1.03 & 4.62 & 6.8 & 3.1 \\
\hline Solar photovoltaic & 12.45 & 12.61 & 12.28 & 1.4 & 18.5 & 19.1 & 17.9 \\
\hline Fossil fuel & 5.39 & 6.73 & 4.45 & 114 & 362 & 477.6 & 296.9 \\
\hline Motor fuels & 5.95 & 6.23 & 5.7 & 264 & 941 & 997.3 & 894.2 \\
\hline
\end{tabular}

Table 4: Energy demand by sector

\begin{tabular}{lccccccc}
\hline Sector & BAU & $\begin{array}{c}\text { Growth rate (\%) } \\
\text { AGS }\end{array}$ & MGS & $\begin{array}{c}\text { 2008 (ktoe) } \\
\text { Base year }\end{array}$ & BAU & $\begin{array}{c}\text { 2030 (ktoe) } \\
\text { AGS }\end{array}$ & MGS \\
\hline Industry & 6.07 & 8.18 & 4.0 & 357.02 & 1306.08 & 2014.33 & 846.83 \\
\hline Manufacturing & 4.64 & 7.28 & 2.35 & 180.22 & 489.23 & 846.47 & 300.28 \\
\hline ACM & 7.2 & 8.96 & 5.26 & 176.8 & 816.84 & 1167.86 & 546.55 \\
\hline Transport & 6.02 & 6.04 & 6.04 & 206.55 & 747.66 & 750.5 & 750.99 \\
\hline Freight & 4.27 & 4.39 & 4.39 & 98.37 & 246.98 & 253.07 & 253.07 \\
\hline Passenger & 7.21 & 7.18 & 7.18 & 108.18 & 500.68 & 497.43 & 497.93 \\
\hline Household & -0.86 & -0.55 & -0.86 & 3455.34 & 2859.22 & 3063.67 & 2859.22 \\
\hline Service & 3.99 & 3.65 & 2.46 & 106.58 & 251.97 & 234.72 & 181.77 \\
\hline
\end{tabular}


the expansion of the electricity industry is necessary.

Table 5 depicts the comparison in electricity demand growth for REF, AGS and MGS scenarios. Sectorial consumption of electricity shows the growth rate of electricity demand for industry to be $14.28 \%, 16.96 \%$ and $11.67 \%$ for REF, AGS and MGS scenarios. Average growth rate for household is $14.7 \%$ for all scenarios. The electricity consumption in the base year was distributed to $44 \%$ for industry, $45 \%$ for household, and $11 \%$ for service. However, the more significant effect observed in the evolution of electricity is the shift from household to industry. Much of the increase is driven by higher demands for electricity in industry to sustain the high economic growth anticipated by the policy makers.

\subsubsection{Final energy demand per capita}

Figure 6 compares per capita energy demand for the REF, AGS and MGS scenarios. Results show decreasing trend in energy demand per capita. Energy demand per capita will decrease continuously from 3.669 MWh in the base year to 3.050 MWh, 3.527 MWh and 2.739 MWh for the REF, AGS and MGS, respectively in the year 2030. Annual growth rates of energy demand per capita of $-0.84 \%,-0.18 \%$ and $-1.32 \%$ are observed for REF, AGs and MGS scenarios respectively.

\subsubsection{Energy intensity}

Figure 7 compares the evolution of energy intensity for the REF, AGS and MGS scenarios. The analysis show energy intensity decreasing at $-5.58 \%$ reaching $3.875 \mathrm{kWh} / \mathrm{US} \$$ in REF scenario by 2030 against base year value of $13.714 \mathrm{kWh} / \mathrm{US} \$$. The growth rates for AGS and MGS are projected at $6.7 \%$ and $-4.25 \%$ reaching $2.982 \mathrm{kWh} / \mathrm{US} \$$ and $5.271 \mathrm{kWh} / \mathrm{US} \$$ in 2030 , respectively. The projected decrease in energy intensity is brought about mainly by improvement in technological energy efficiency in industry, service, household and transport. A high decrease rate in the AGS scenario is due to these changes while low decrease in the MGS scenario is due to less improvement.

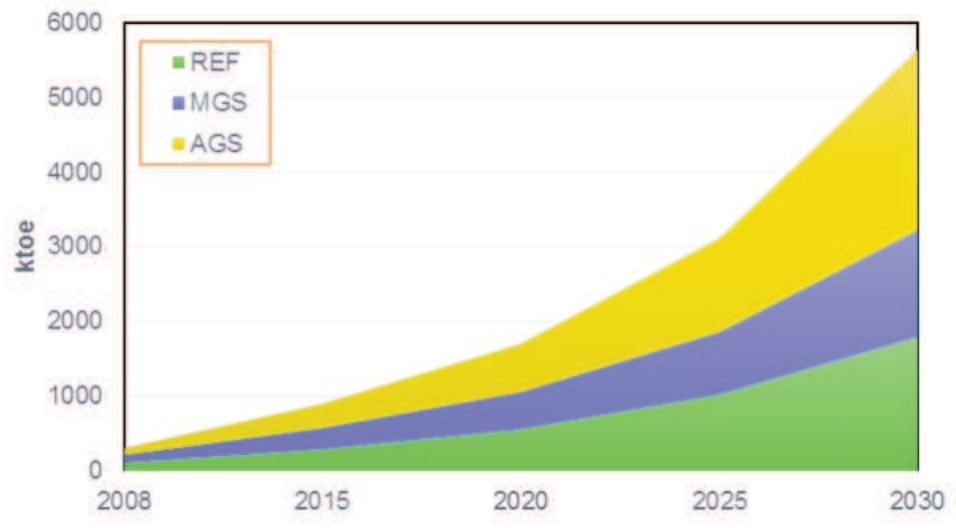

Figure 4: Projected electricity demand

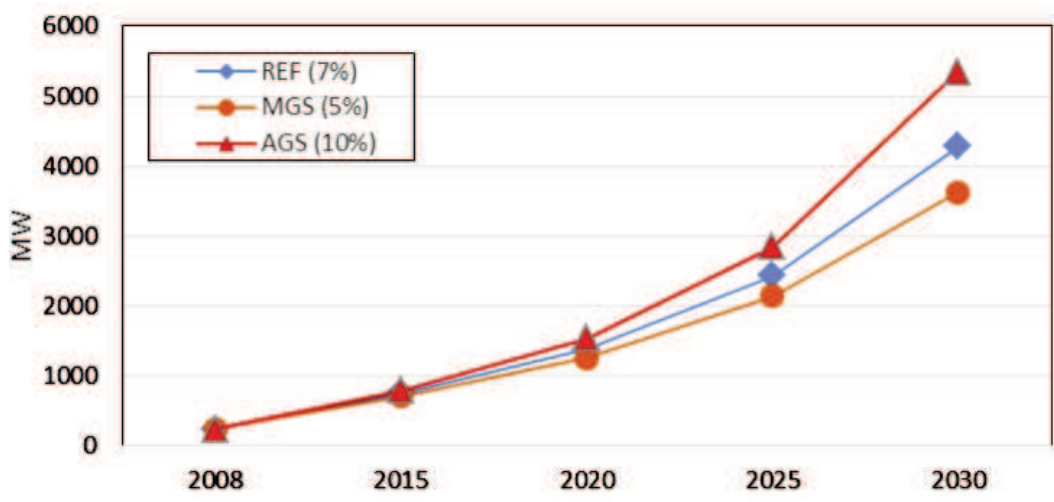

Figure 5: Electricity demand (peak) projections, MW

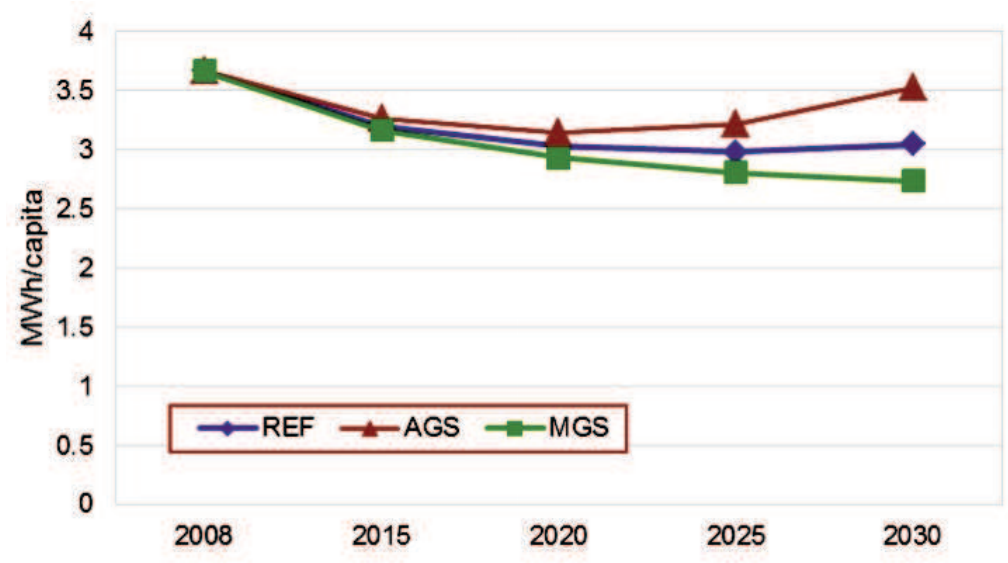

Figure 6: Final energy per capita

Table 5: Sectorial demand

\begin{tabular}{|c|c|c|c|c|c|c|c|}
\hline \multirow[t]{2}{*}{ Sector } & \multicolumn{3}{|c|}{ Growth rate (\%) } & \multirow{2}{*}{$\begin{array}{c}2008 \text { (ktoe) } \\
\text { Base year }\end{array}$} & \multicolumn{3}{|c|}{2030 (ktoe) } \\
\hline & $B A U$ & AGS & MGS & & $B A U$ & AGS & MGS \\
\hline Industry & 14.28 & 16.96 & 11.67 & 42.03 & 791.67 & 1320.33 & 476.4 \\
\hline Manufacturing & 10.58 & 14.00 & 8.09 & 32.03 & 292.68 & 511.784 & 177.52 \\
\hline $\mathrm{ACM}$ & 19.45 & 22.10 & 16.70 & 10.00 & 498.99 & 808.54 & 298.87 \\
\hline Transport & - & - & - & 0 & 0.273 & 0.163 & 0.163 \\
\hline Freight & - & - & - & 0 & 0.11 & 0 & 0 \\
\hline Passenger & - & - & - & 0 & 0.163 & 0.163 & 0.163 \\
\hline Household & 14.7 & 14.7 & 14.7 & 39.30 & 802.52 & 802.52 & 802.52 \\
\hline Service & 10.29 & 11.88 & 8.76 & 23.59 & 203.53 & 278.73 & 149.67 \\
\hline
\end{tabular}




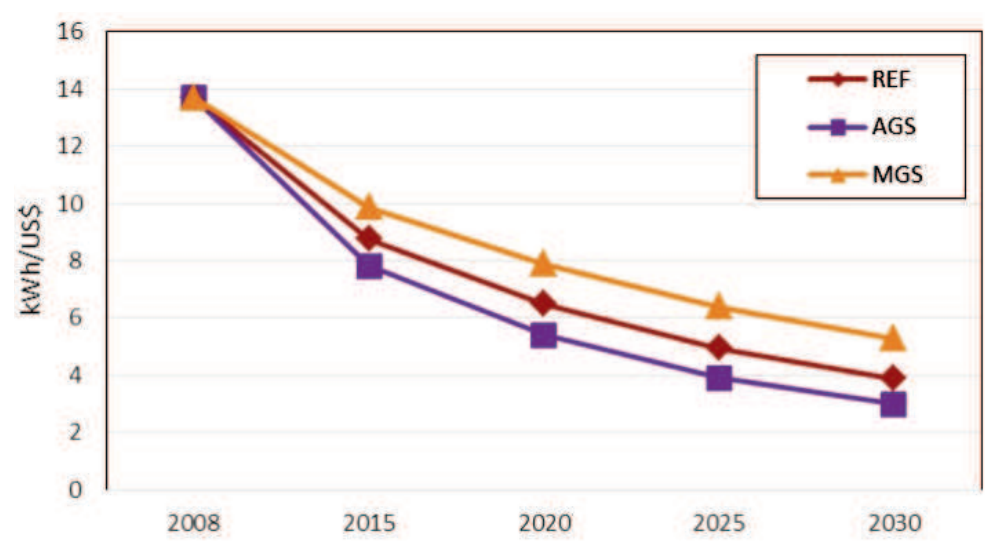

Figure 7: Energy intensity

\section{Supply options and resources}

\subsection{Fossil fuel}

5.1.1 Coal

Coal is Malawi's most abundant fossil resource. Probable coal reserves are estimated at 1 billion metric tonnes, 22 million of which are proven reserves of a bituminous type, with a high ash and low sulphur content. Coal deposits have been found in 15 dispersed locations in the country, the largest being at Ngana in the north, where total proven reserves ${ }^{2}$ have been estimated at 16 million tonnes but could possibly reach as high as 70 million tonnes (GoM, 2010c). Further exploration work might increase the total reserves of coal in the country.

Coal mining started in 1985 and currently two fields are being mined in Rumphi district. Coal extraction is carried out primarily in open-pit mines. The production of coal in Malawi has increased from 34100 metric tons in 2001 to 79186 metric tons in 2010 (GoM, 2010c). At present coal is predominantly used as an energy source for process heat mainly in tobacco processing, textile and sugar production, and beer brewing as well as cement production. The country plans to install two coalfired power stations at Zalewa and Salima with capacity of $300 \mathrm{MW}$ and $100 \mathrm{MW}$ respectively

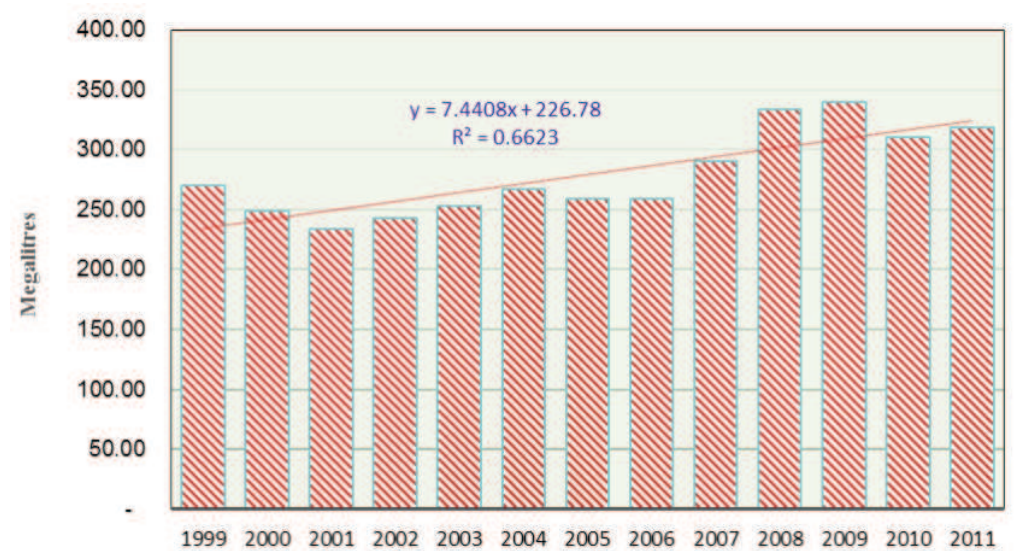

Figure 8: Consumption of petroleum products 1999-2011 Source: MERA
(Chiyembekeza, 2013). Compared to nuclear and solar, coal is preferable as energy source in Malawi due to its relatively low price and abundance. However, there will be need to invest in new production equipment, quality, environmental stewardship and transport infrastructure.

\subsubsection{Hydrocarbon resources}

Malawi does not have oil deposits, and relies entirely on imported petroleum products. However, some past studies have shown the existence of some hydrocarbon resources in the northern part of Lake Malawi and in the lower Shire Valley, although the quantities are not certain. Exploration work by two companies, Surestream Petroleum Limited and Simkara continues under agreements with the Government of Malawi. Currently, Malawi imports $97 \%$ of its refined petroleum products and the remaining $3 \%$ from locally produced ethanol fuel (NCST, 2011). The country imports about 8000 barrels per day while the average daily fuel demand is currently estimated at 1.124 million litres which translates to 33.6 million litres per month or annual budget equivalent of US\$366 million (Lanjesi, 2011). All petroleum products are imported into the country via three routes Dar Corridor (Tanzania), Nacala and Beira Corridor (Mozambique). The import bill has been continuously increasing in recent years which impose a serious financial burden on a developing country that already suffers the problem of huge public debt. The total annual import bill for the year 2005 accounted for $8.8 \%$ of the total imports. Imports of petroleum from the year 1999 onwards are given in Figure 8 (GoM, 2011). A major consumer of the liquid fuel is the transportation sector $(89.99 \%)$, followed by domestic $(5.25 \%)$, industry $(2.87 \%)$, and agriculture (1.9\%).

The demand for petrol and diesel is dependent on the growth of road infrastructure, the price of oil, the future efficiency of vehicles, the growth of alternate modes of transport and the emergence of substitutes like biofuels. Due to rapid growth of the number of vehicles, the demand for petroleum products will witness a growth in demand and it is expected to rise to more than 400 million litres by 2015 , which will further increase to around 560 million litres by 2030 considering a high output growth (NCST, 2011).

\subsubsection{Uranium}

Nuclear technology has been playing an important role in medicine, industry, science, and food and agriculture, as well as power generation. Malawi has relatively small uranium reserves, therefore as a nuclear fuel of the future has a special importance for the country. The known recoverable resource of uranium in Malawi at Kayelekera Mine is estimated at 63000 tons, which is equivalent to 378 tons of 
U-235 (GoM, 2003). ${ }^{3}$ Another deposit which is yet to be quantified is at Illomba in Chitipa district. If used to generate electricity in conventional reactors, these reserves would equate to $458.5 \mathrm{PJ}$ of energy. Mining of uranium started in 2008 at Kayelekera but currently all the extracted uranium is exported to Canada for enrichment. The country's annual production output in 2010 was estimated at 790 tons of uranium (U308), which generated about $\$ 133.9$ million, accounting for nearly $10 \%$ of Malawi's exports by value. Malawi is considering installing nuclear power to cope with future energy demand increases. Growing electricity demand, fluctuation of fossil fuel prices and climate change pressure bring all in favour of nuclear power. Under the Malawi Electricity Investment Plan, the first 125 MW nuclear power plant is expected to start operating by 2050 and will contribute to $4 \%$ of the total energy supply in Malawi (GoM, 2010a).

\subsection{Renewable energy resources}

Malawi has a large potential for renewable energy exploitation in a number of areas, the significant ones being solar energy, biomass, and hydropower with potential for geothermal and wind energy. Except for large scale hydropower, which serves as a major source of electricity, the current state of exploitation and utilization of the renewable energy sources in the country is very low, limited largely to pilot and demonstration projects. This section gives a review on the available energy potential of different renewable energy sources and the current status of exploitation is presented.

\subsubsection{Hydro}

Malawi has an estimated gross theoretical potential of $1670 \mathrm{MW}$ and the average power generation of $15000 \mathrm{GWh} /$ year. The technical and economically feasible hydro capacity has been estimated at 6000 and $7000 \mathrm{GWh} /$ year, respectively (Taulo, 2007). Current hydropower generation is about $17 \%$ of the nation's hydropower potential and represents $98 \%$ of total installed grid-connected electricity generation capacity. Hydropower potential of Malawi is concentrated on the Shire River. The capacity ranges from 18 to $140 \mathrm{MW}$. The estimated hydro potential of the Shire River is about $600 \mathrm{MW}$, equivalent to an annual production of $3500 \mathrm{GWh}$ (ibid). In addition, several smaller rivers such as the Songwe, South Rukuru, Dwangwa and Bua, have limited potential at a number of sites estimated to total about 300-400 MW (WEC, 2002).

In addition, Malawi also has huge untapped small hydropower potential (with capacities of less than $10 \mathrm{MW}$ each) which are spread out across the country. The gross theoretical small hydro potential of the country is $150 \mathrm{MW}$, out of which only 4.5 MW of the economically feasible potential has been developed (MEM, 1997). The exploitability of these is limited by their projected costs, but they could be useful for off-grid or stand-alone-mini grid electrification.

\subsubsection{Solar energy}

Solar energy presents considerable potential that can contribute to a large extent to fill the gap of energy needs in Malawi. The country receives about 2138 to 3087 hours of sunshine and 2133 $\mathrm{kWh} / \mathrm{m}^{2} /$ year. The global solar radiation on a horizontal surface ranges between $4.3 \mathrm{kWh} / \mathrm{m}^{2} /$ day minimum and $7 \mathrm{kWh} / \mathrm{m}^{2} /$ day maximum. The annual daily mean global solar radiation is about 5.86 $\mathrm{kWh} / \mathrm{m}^{2} /$ day, equivalent to 250 million tonnes of oil equivalent. Maximum irradiation of 6.5-7.0 $\mathrm{kWh} / \mathrm{m}^{2} /$ day occurs in September - October and the minimum of $4.3-4.6 \mathrm{kWh} / \mathrm{m}^{2} /$ day occurs in January-February or in June-July according to location. Peak hourly solar radiation is more than $1000 \mathrm{kWh} / \mathrm{m}^{2}$ during November to December (Chima, 1998). Considering that many parts of the country receive 8 to 12 hours of sunshine per day of $244 \mathrm{~W} / \mathrm{m}^{2}$, the potential for using solar for electricity generation is very high. The total available solar energy potential over the total geographical area (i.e. $94,280 \mathrm{~km}^{2}$ ), of Malawi is calculated to be 356,284,837 MWh/year.

The solar resource in Malawi has been employed for various applications. Solar water heaters have been developed and are manufactured locally for domestic purposes. Total amount of installed solar water heaters in the country is estimated to have reached approximately 4855 square meters. In addition, photovoltaic systems are also finding increasing use for various purposes such as lighting, water pumping, telecommunications repeater stations, refrigeration, and other appropriate applications. At present, there are more than 10 000 photovoltaic systems installed in various parts of the country, with a total capacity of $165 \mathrm{kWp}$ (CSR, 2005). There has been further growth, though small, in the SHS but no accurate figures are currently available. Six solar-wind hybrid systems have also been installed with Department of Energy Affairs support in Thyolo, Chiradzulu, Nkhata Bay, Mzimba, Nkhota-kota and Ntcheu $(12 \mathrm{~kW}$, each providing power for about 150 households). More recently, an $870 \mathrm{kWp}$ solar photovoltaic plant has been commissioned at Lilongwe International Airport.

\subsubsection{Wind energy}

Wind energy has been used on a small scale to supply water for both livestock and irrigation in Malawi. Although there is a dearth of information on the wind energy characteristics of the country, it seems the wind speeds are moderate to low, typically in the range of $2.0-7.0$ metres/second (GoM, 2003). Preliminary results from studies conducted by 
Malawi's Meteorological Department suggest that the wind resource in Malawi cannot contribute significantly to a firm power generation; and that low speed aerogenerators could be operated for various applications such as milling of grains, pumping water and even lighting purposes in small remote villages around Malawi. It is particularly suited to water pumping as intermittent wind could still supply the needs when an adequate storage facility is incorporated. However, such assertion is contrasted by recent research findings which indicate that there is considerable potential for wind in the country. At present, the DoEA is collaborating with Malawi Renewable Energy Acceleration Programme (MREAP) at the University of Malawi, an initiative funded by the Scottish Government, to undertake detailed wind measurements at five strategic sites as part of developing Malawi's wind atlas.

\subsubsection{Biomass and bioenergy}

Biomass in the form of wood fuel is the largest form of primary energy consumed in Malawi, accounting for $97 \%$ of the total primary energy supply in the country (GoM, 2010b). Major sources of biomass available include fuelwood and forestry residues, agricultural residues, animal dung, energy crops and municipal wastes. Forest reserves are the main sources of fuelwood and contribute nearly $75 \%$ of the total biomass supply (Jumbe and Angelsen, 2011). Forests cover 3.2 million hectares, approximately $36 \%$ of the total land area with total available biomass resources being 275.5 million tonnes (Kambewa and Chiwaula, 2010). Sustainable fuel wood supplies from forests are estimated to be 42.4 million cubic metres of solid wood equivalent. Total demand for biomass energy is estimated at 8.92 million total wood equivalent or 13.38 million cubic metres solid wood

Total bioenergy potential in Malawi is estimated between 0.1 and $0.5 \mathrm{EJ} /$ year (Zyl et al, 2010). Crop residues have the biggest energy potential about $161910 \mathrm{TJ} /$ year, followed by forest residues (48 $744 \mathrm{TJ})$. In addition, there are approximately 23 million animals (cattle, goats, sheep, pigs and chickens) and their manure can be used for the production of biogas (FAO, 2010). This number of animals gives a theoretical potential for biogas production of $1,387,195 \mathrm{~m}^{3}$ of biogas per day corresponding to $1100 \mathrm{GWh}_{e} /$ year of electricity or 914.5 $\mathrm{GWh}_{\mathrm{th}} / \mathrm{y}$ of heat, assuming an average of 2.25 $\mathrm{kWh} / \mathrm{m}^{3}$. This is about $74 \%$ of the electricity consumed in Malawi (electricity consumption amounted to $1478 \mathrm{GWh}$ in 2012). In view of rising consumption, which is expected to quadruple over 2008 to 2030, using biogas to generate electricity could be a sensible way of improving electricity supply mix in Malawi.

Annual average production of sugarcane in Malawi is estimated at 2.5 million tons/year leaving behind over 950000 tons baggase which is a significant power source. There are two sugar mills in Malawi having potential to generate 62 MWe of electricity but currently only 18 MWe has been utilised. Bagasse-based electrical generation estimated at $251 \mathrm{GWh}$, corresponds to about $25 \%$ of national electricity generation (UNEP, 2013). The country can also explore biogas potential of municipal solid waste (MSW) as well. Current estimated municipal solid waste (MSW) generation per day is 720 tons which gives theoretical potential for biogas production of $32,683 \mathrm{~m}^{3} /$ day corresponding to 70.6 $\mathrm{MWh}_{\mathrm{e}} / \mathrm{y}$ or $58.8 \mathrm{MWh}_{\mathrm{th}} / \mathrm{y}$ (Karekezi et al., 2003).

Moreover, agricultural residues such as rice straw, sugarcane and cassava pulp have the potential to produce approximately 46.5 million litres ethanol production for the country. This could possibly displace over 40\% of Malawi's 2011 petrol consumption as transport fuel. Alternatively, the same amount of residue could provide 18.1 million litres per year of diesel to potentially offset $9.5 \%$ of natural diesel consumption in the transport sector. Presently, molasses-based ethanol amounting to 18 million litres/year, is being marketed as $10 \%$ blend with petrol. The total demand for ethanol is expected to be 33.6 million litres against present availability, resulting in scarcity of 15.6 million litres ethanol in the year 2015. Furthermore, biodiesel produced from energy crops such as Jatropha curcas, soya beans, cotton, sunflower and groundnuts has the potential to produce 50 million litres of biodiesel, equivalent to $583,530 \mathrm{TJ} /$ year of energy.

\subsubsection{Geothermal energy}

Geothermal energy has been extensively used for power generation and direct power applications in many countries of the world (Fridleifsson, 2003). As a consequence of Malawi's location in the East African Rift System (EARS), the country is endowed with significant potential reserves of geothermal energy. There are approximately 55 geothermal spots in Malawi, but three major ones identified for detailed investigation are: Chiweta, Mwankeja, and Nkhotakota. The combined geothermal potential from these major areas is $200 \mathrm{MWe}$ (Gondwe et al., 2012). As for geothermal projects, some studies have been conducted to design a prototype Geothermal Power Plant for producing electricity. One of the ongoing related projects is a $30 \mathrm{MW}$ Geothermal Power Plant at exploring stage in Nkhotakota, to be upgraded to $100 \mathrm{MW}$ depending on the results of exploration drilling.

\section{Issues}

Despite these options, there are several issues facing the energy sector and crucial to economic development. The main energy challenges that face Malawi presently is how to increase energy supplies to meet the needs of its growing population; also significant 
is the need to repair and upgrade existing infrastructure for non-hydrocarbon energy sources. Meeting these challenges is critical to improving the nation's economy and raising the standard of living in Malawi.

\subsection{Deforestation}

Widespread inefficient production and use of traditional energy sources such as fuelwood and charcoal, has contributed to deforestation. Between 1990 and 2010, forest cover has declined from $41 \%$ to $34 \%$ (FAO, 2010). The resultant deforestation degrades catchment areas leading to siltation and reduced base flows in rivers. Use of biomass as a source of energy and clearing of natural woodlands for agricultural expansions are among factors that have contributed to the rate of deforestation.

\subsection{Inadequate and unreliable power supply} Lack of adequate and reliable power is consistently cited by private sector firms as being among the top five constraints on Malawi's economic growth. There is insufficient power supply due to the current diminished generation capacity which is a direct result of low hydraulic head, siltation and weed infestation. Inevitably, the energy sector is also affected by extreme weather events such as droughts and floods, which negatively impact on hydropower generation along the Shire River. The water flow disruptions have been exacerbated by siltation caused by poor and unsustainable agriculture practices and deforestation in the catchment area, and invasive weeds such as water hyacinth.

\subsection{Ensuring energy access}

Very low electricity coverage throughout the country, especially in rural areas, is a critical challenge. In Malawi, about $10 \%$ of households are supplied with electricity from the national grid and most of these are in urban centres. Only $2 \%$ of rural households are electrified despite the fact that $85 \%$ of people in Malawi reside in rural areas. The situation is unlikely to improve in the short term. For Malawi, access goes beyond the grid power being available but also affordable. The MAREP effort could have easily yielded 20 to $25 \%$ access to grid electricity if the rural population was also economically empowered to afford paying for upfront costs of wiring, inspection and connection. This calls for an innovative model for rural energy access beyond the grid extension.

\subsection{Security of energy supply}

A key issue for Malawi's energy security is its dependence on imported petroleum products. The country is highly vulnerable to oil price shocks as it imports almost all of its 8000 barrels of oil per day. There is no doubt that the challenge for Malawi's import dependence will increase at least in the short to medium term. Firstly, the country's demand is still growing, hence further import increase is inevitable; secondly, Malawi is a price taker in the global oil market, so any international price hike will have a direct impact on Malawi's current account and; finally, as seen recently, a depreciation of Malawi's currency will also push up the import bill. Additionally, the costs of transportation of the petroleum products from sea ports (Beira, Nacala, Dare Salaam and Durban) are high. There is also low storage capacity for petroleum products compared to national requirements. The Southern Africa region is projected to experience increased intensity and frequency of extreme climate events such as floods and droughts. Since $98 \%$ of national grid electricity is from hydro, Malawi's electricity supply is considered vulnerable to the impacts of climate variability and climate change.

\subsection{Energy investment needs}

The country's energy consumption is forecasted to grow at an average rate of $7 \%$ to sustain economic growth of $6 \%$ per annum to the year 2030. This increased energy demand would require significant investments in the energy infrastructure. This is especially necessary to provide modern energy to the large proportion of the country's population, whose energy demand is currently unmet. According to GoM (2010a), Malawi would need a total investment of US $\$ 2.1$ billion on overall energy supply infrastructure from 2011 to 2030. This is a substantial amount, considering that the Malawi government annual budget for total capital expenditure is less than US\$10million. Ensuring this scale of investment for the next two decades will be a challenge for Malawi, making private investment crucial.

\subsection{Aging infrastructure}

Aging transmission and distribution infrastructure causes high transmission and distribution losses and drives the power system to be highly vulnerable. Over $50 \%$ of the power generation plants in Malawi have passed their expected lifespans and hence require frequent maintenance in order to improve on efficiency of the machines. The average age profile for the transmission infrastructure is around 30 years. Additionally, the system experiences termite attacks and natural rotting of wood structures. Other problems include bush fires leading to burning of wooden poles, and even vandalism on both wood and steel tower structures.

\subsection{High transmission and distribution losses}

Transmission losses in Malawi continue to be amongst the highest in the world, and reducing losses or improving transmission efficiency is the main concern in the electric power sector. The overall 
transmission losses are estimated to be currently $21 \%$, with around $14 \%$ being technical losses (MCA, 2010). High losses in the distribution systems are mainly due to the aging systems, with inadequate investments over the past years resulting in unplanned extensions of distribution lines and the overloading of systems equipment such as transformers and conductors.

\subsection{Operational aspects}

Floating aquatic weeds and debris being transported in the Shire River have caused severe operational problems and damage to intake structures at the generation plants. Siltation of power plants reservoirs has also contributed immensely to the operational problems. In addition, theft and vandalism of ESCOM infrastructure; illegal connection of electricity; encroachment of ESCOM Way-leave; as well as illegal extension of electricity has resulted in contributed to huge financial losses.

\section{Conclusion}

This paper presents an overview of the current status of the energy sector in Malawi in terms of its total energy demand and supply, options and issues in the present and future. The study found that the present energy scenario of the country is not satisfactory, as the existing power shortage is at $14 \%$. While there has been some progress in recent years, shortage of energy and lack of access continues to be a major constraint to economic growth. The persistent shortages of electricity indicate the need for improving performance of the energy sector in the country. To cope with the expected increase in electricity consumption, electricity generation capacity must increase. The country is also heavily dependent on biomass and importation of oil as a source of primary energy supply, and it is likely to remain so for decades. This dependence on expensive imported energy resources place a huge burden on the economy and air pollution is becoming a great environmental concern in the country. Therefore, the Malawi Government energy planners should take due consideration of social, economic and environmental factors to ensure a resilient and sustainable future energy mix for the country.

There is considerable opportunity for Malawi to meet its future demand and thus economic growing through renewable energy. Since renewable energy supply in Malawi is dominated by hydropower and biomass, the share of bioenergy is expected to increases with the expansion of other renewables. There is potential for solar and wind development. The paper also discussed some of the issues facing the energy sector in Malawi. Malawi is rapidly running out of generating capacity and must build new power stations soon. The only two indigenous sources for bulk electricity are hydro and coal, since oil reserves are unknown and small hydro, wind and solar power only have limited potential, developing new hydro power schemes is a probability.

The following strategies need to be considered

to secure Malawi's energy supply:

1. Enlarge the use of domestic energy resources through promotion of renewable energy projects such as small hydro power; cogeneration with sugarcane, tea and timber factories, increased use of solar to generate electricity.

2. Diversify energy supply by interconnecting and importing electricity from Caborra Bassa in Mozambique as well as building coal-fired plants using modern cleaner technologies.

3. Continue with the development of Malawi's power sector by the optimal way, minimising the environmental impacts and expected investment and operational costs.

4. Accelerate energy conservation and efficiency including development of technical personnel and energy efficient technologies. For future interest, Malawi should pay more attention to the optimization of consumption of energy resources, power system and final energy consumption by the vector objectives, minimizing the cost of energy resources, environmental impact, operating costs and investment costs.

5. Reduce oil dependency by promoting plug-in hybrid engines, increase percentage of ethanolpetrol blend from $20 \%$ to higher levels, biofuels (as biodiesel or $100 \%$ ethanol) and other technologies. Fiscal incentives such as duty free importation of hybrid vehicles, government procurement of such vehicles for its fleet, and legislation on compulsory blending of fuel are likely to be helpful.

\section{Acronyms and abbreviations}

CSR Centre for Social Research

ESCOM Electricity Supply Corporation of

FAO $\quad$ Malawi

GDP Gross Domestic Product

GoM Government of Malawi

GWh Giga Watt hour

Ktoe Kilotonnes of oil equivalent

MAREP Malawi Rural Electrification Programme

MCA Millennium Challenge Account

MCC Millennium Challenge Corporation

MERA Malawi Energy Regulatory Authority

M-REAP Malawi Renewable Energy Acceleration Programme

MSW Municipal Solid Wastes

Mtoe Million tonnes of oil equivalent

MW Mega watts

MWe Megawatt (electrical)

MWth Megawatts (thermal)

NCST National Commission for Science and Technology 


$\begin{array}{ll}\text { NEP } & \text { National Energy Policy } \\ \text { NSO } & \text { National Statistical Office } \\ \text { UNDP } & \text { United Nations Development } \\ & \begin{array}{l}\text { Programme } \\ \text { WEC }\end{array} \\ \text { World Energy Council }\end{array}$

\section{Notes}

1. In this paper, renewable energy technologies refer small hydro, geothermal, wind, cogeneration and biomass-based power generation, and solar technologies and exclude large hydropower.

2. Proven reserves are those for which further exploration is not required for mine planning

3. There are $85 \mathrm{~kg}$ of uranium in $100 \mathrm{~kg}$ of uranium oxide. Of these $85 \mathrm{~kg}$, only $0.7 \%$ is U-235. i.e. there are $0.6 \mathrm{~kg}$ of $\mathrm{u}-235$ in $100 \mathrm{~kg}$ of $\mathrm{U}_{3} \mathrm{O}_{8}$.

\section{Acknowledgements}

The authors gratefully acknowledge funding from the Department of Mechanical and Mechatronics Engineering, at Stellenbosch University. Further, they are indebted to the Ministry of Energy for their provision of much of the data used in this paper.

\section{References}

Chima, T. (1998). Study on Assessment of Alternative Energy Resources in Malawi. Consultancy Report, prepared for Department of Energy Affairs and Danish Aid for International Development Assistance.

Chiyembekeza, C. (2012). China invests $\$ 500 \mathrm{~m}$ for electricity in Malawi, The Nation, Vol. 19. No.14, September 26, 2012.

CSR, (2005). Baseline Inventory/Development Impact of Solar Photovoltaic and Thermal Systems in Malawi, Final Report; Centre for Social Research, University of Malawi, Zomba.

ESCOM, (2011). Annual Report,' Electricity Supply Corporation of Malawi, Blantyre.

FAO, (2010). Global Forest Resources Assessment 2010: Country Report Malawi. Food and Agricultural Organization, Rome.

Fridleifsson, I.B., (2003). The Role of Geothermal Energy in the World. United Nations Geothermal Training Programme, Reykjavik, Iceland.

Gamula, G.E.T., Hui, L. \& Peng, W. (2013. Contribution of the Energy Sector towards Global Warming in Malawi, Energy and Power Engineering (5): 284292.

Gondwe, K., Allen, A., Georgsson, L., Loga, U., \& Tsokonombwe, G. (2012). Geothermal Development in Malawi - a Country Update. Proceedings 4th African Rift Geothermal Conference, Nairobi, Kenya, 21-23 November 2012.

Gooneratne, F., \& Visser, A. (2010). Malawi: Development of a large-Scale Energy Efficient Lighting Program - CFL Program Design and Implementation Plan, Final Report. The TI-UP Resource Centre.

Government of Malawi, (2003). Malawi Energy Policy.
Ministry of Energy and Mining, Lilongwe.

Government of Malawi, (2010a). Malawi Electricity Investment Plan. Department of Energy Affairs, Lilongwe.

Government of Malawi, (2003). Malawi Energy Policy. Ministry of Energy and Mining, Lilongwe.

Government of Malawi, 2010b. Energy Demand Assessment for Malawi (Final Report to IAEA). Department of Energy Affairs, Lilongwe.

Government of Malawi, (2010c). Malawi State of Environment and Outlook Report: Environment for Sustainable Economic Growth. Ministry of Natural Resources, Energy and Environment, Lilongwe.

Government of Malawi, (2011). Annual Economic Report. Ministry of Economic Planning and Development.

Government of Malawi, (2012). Malawi Growth and Development Strategy II (2011-2016). Ministry of Economic Planning and Development, Lilongwe.

IEA, (2010). Key World Energy Statistics 2010. OECD/IEA, Paris.

Jumbe, B.L. \& Angelsen, A. (2011). Modelling choice of fuelwood source among rural households in Malawi: A multinomial probit analysis, Energy Economics 33: 732-738.

Jumbe, C.B. (2004). Cointegration and casuality between electricity consumption and GDP/empirical evidence Evidence from Malawi, Energy Economics 26(1):61-68.

Kambewa, P. \& Chiwaula, L. (2010). Biomass energy use in Malawi: A background paper prepared for the International Institute for Environment and Development (IIED) for an international workshop on biomass energy, 19-21 October 2010, Parliament House Hotel, Edinburgh.

Karekezi, S, Kimani, J, Maina, A, Wangeci, J \& Mutiga, A. (2003). Overcoming Barriers to the Use of Renewable Energy and Energy Efficiency Systems in the Reforming Power Sector of Eastern Africa Background paper for Eastern Africa Renewable Energy and Energy Efficiency Partnership (REEEP) Regional Consultation Workshop.

Kaunda, C.S. (2013). Energy situation, potential and application status of small-scale hydropower systems in Malawi. Renewable and Sustainable Energy Reviews (26): 1-19.

Kaunda, C.S., \& Mtalo, F. (2013). Impacts of environmental degradation and climate change on electricity generation in Malawi. International Journal of Energy and Environment 4(1):481-496.

Kiplagat, J.K., Wang, R.Z., Li, \&T.X. (2011). Renewable energy in Kenya: Resource potentials and status of exploitation. Renewable and Sustainable Energy Reviews 15: 2960-2973.

Koopmans, A., \& Koppejan, J. (1997). Agricultural and Forest Residues-Generation, Utilization and Availability. Regional Consultation on Modern Application of Biomass Energy, Kuala Lumpur, Malaysia.

Lanjesi, D. (2011). Economic Forum Seminar Report on Procurement and Management of Fuel Supplies in Malawi. 20 October, 2011, Hotel Victoria, Blantyre. MCA, (2010). Concept Paper for the Energy Sector. 
Millennium Challenge Account, Malawi Country

Office Secretariat, Lilongwe, Malawi.

MCC, (2011). Malawi Power System Project Studies -

Final Feasibility Study Report. Millennium Challenge

Corporation, Washington DC.

MEM, (1997). National Sustainable and Renewable

Energy Programme. Ministry of Energy and Mining,

Lilongwe, Malawi.

NCST, (2011). Ethanol Driven Vehicle Project-

Assessment of the Use of Ethanol as an Alternative

Vehicle Fuel to Petrol in Malawi. National

Commission for Science and Technology (NCST),

Lilongwe, Malawi.

NSO, (2009). Population and Housing Census: Main

Report. National Statistical Office, Zomba, Malawi.

Openshaw, K. (2010). Biomass energy: Employment

generation and its contribution to poverty alleviation. Biomass and Bioenergy (34): 365-378.

Taulo, J.L. (2007). A study on the utilization of smallscale hydropower for rural electrification in Malawi. Master's thesis, University of Cape Town.

UNDP, (2013). Human Development Report 2013. United Nations Development Programme (UNDP), New York, USA. Accessed on: http://hdr.undp.org.

UNEP, (2013). Emission Reduction Profile - Malawi. United Nations Environmental Programme, Denmark.

Venendaal, R. (1996). Malawi Power Production with Bio-mass: A Feasibility Study Report. Biomass Technology Group, Enschede, Netherlands.

WEC, (2002). Survey of Energy Resources: Hydropower, World Energy Council.

World Bank, (2011). World Development Indicators. The World Bank, Washington DC, USA.

World Bank, (2001). World Development Report 2000/2001: Attacking Poverty. Selected World Development Indicators, Table 10, Energy Use and Emissions (New York: Oxford University Press, 2001.

Zyl, V., Gorgens, J.F., Chimphango, A.F.A. \& Chirwa, P.W.C. (2010). Bioenergy Potential in Sub-Saharan Africa. 17-19 March 2010, Stellenbosch University, South Africa.

Received 28 April 2014; revised 9 April 2015 